\title{
Congenital hyperinsulinism: current status and future perspectives
}

\author{
Tohru Yorifuji, MD, PhD \\ Department of Pediatric \\ Endocrinology and Metabolism, \\ Children's Medical Center, Osaka \\ City General Hospital, Osaka, Japan
}

\begin{abstract}
The diagnosis and treatment of congenital hyperinsulinism $(\mathrm{CHI})$ have made a remarkable progress over the past 20 years and, currently, it is relatively rare to see patients who are left with severe psychomotor delay. The improvement was made possible by the recent developments in the understanding of the molecular and pathological basis of $\mathrm{CHI}$. Known etiologies include inactivating mutations of the $\mathrm{K}_{\mathrm{ATP}}$ channel genes (ABCC8 and KCNJ11) and HNF4A, HNF1A, HADH, and UCP2 or activating mutations of GLUD1, GCK, and SLC16A1. The understanding of the focal form of $\mathrm{K}_{\text {ATP }}$ channel $\mathrm{CHI}$ and its detection by ${ }^{18} \mathrm{~F}$-fluoro-L-DOPA positron emission tomography have revolutionized the management of $\mathrm{CHI}$, and many patients can be cured without postoperative diabetes mellitus. The incidence of the focal form appears to be higher in Asian countries; therefore, the establishment of treatment systems is even more important in this population. In addition to diazoxide or longterm subcutaneous infusion of octreotide or glucagon, long-acting octreotide or lanreotide have also been used successfully until spontaneous remission. Because of these medications, near-total pancreatectomy is less often performed even for the diazoxide-unresponsive diffuse form of $\mathrm{CHI}$. Other promising medications include pasireotide, small-molecule correctors such as sulfonylurea or carbamazepine, GLP1 receptor antagonists, or mammalian target of rapamycin inhibitors. Unsolved questions in this field include the identification of the remaining genes responsible for $\mathrm{CHI}$, the mechanisms leading to transient $\mathrm{CHI}$, and the mechanisms responsible for the spontaneous remission of $\mathrm{CHI}$. This article reviews recent developments and hypothesis regarding these questions.
\end{abstract}

Keywords: Hyperinsulinism, Congenital, Hypoglycemia
Received: 4 April, 2014

Accepted: 14 April, 2014

Address for correspondence:

Tohru Yorifuji, MD, PhD

Department of Pediatric

Endocrinology and Metabolism,

Children's Medical Center, Osaka

City General Hospital, 2-13-22

Miyakojima-Hondori, Miyakojima,

Osaka 534-0021, Japan

Tel: +81-6-6929-1221

Fax: +81-6-6929-1090

E-mail: t-yorifuji@hospital.city.osaka.jp

\section{Introduction}

Congenital hyperinsulinism (CHI) is the most common cause of persistent hypoglycemia in infancy, and severe hypoglycemia in infancy can cause permanent brain damage ${ }^{1-4)}$; therefore, optimal management is extremely important. In the past, our armamentarium against severe $\mathrm{CHI}$ was very limited. With only diazoxide and near-total pancreatectomy as available options, many patients were left with psychomotor delay or epilepsy. Even worse, a number of patients developed postoperative insulin-dependent diabetes mellitus ${ }^{3,5,6)}$.

Over the past 20 years, however, remarkable progress has been made in the diagnosis and management of CHI, which has directly translated into improved neurological outcomes for patients ${ }^{3,7)}$. This improvement in the understanding of the pathogenesis of CHI and the development of diagnostic modalities have helped in deciding the optimal management strategy for each patient ${ }^{8-10)}$. However, the situation is still far from ideal. Several unsolved questions and unmet needs remain.

In this review, I first discuss the diagnostic criteria and the practical treatment goals for $\mathrm{CHI}$, which are the prerequisites for all subsequent management. Then, after a brief introduction of 
the mechanism of glucose-induced insulin secretion, I review the current status of the understanding and management of CHI. Finally, I list some of the unsolved questions in this field and introduce key findings that may guide us in the future.

\section{Diagnostic criteria and treatment goals for $\mathrm{CHI}$}

\section{Diagnosis of $\mathrm{CHI}$ (Table 1)}

To diagnose hyperinsulinemic hypoglycemia (HI), physicians rely both on clinical clues to identify hyperinsulinism and on laboratory tests to prove hyperinsulinemia.

\section{1) Clinical clues to suspect HI}

The presence of $\mathrm{HI}$ may be suspected even when the patient is still in an emergency room by asking three questions: When did hypoglycemia develop after the last meal? Does the patient respond to glucagon injection? What is the amount of glucose infusion needed to keep the patient euglycemic?

(1) When did hypoglycemia develop after the last meal?

Euglycemia is maintained by a balance between hepatic glucose output and peripheral uptake induced by insulin. Hepatic glucose output is determined by three factors: food absorption, glycogenolysis, and gluconeogenesis. Fig. 1 shows the duration of glucose production by each of these mechanisms. In disorders of glycogenolysis, the patient typically becomes hypoglycemic after $4-5$ hours of fasting. Similarly, in disorders of gluconeogenesis, the patient typically develops

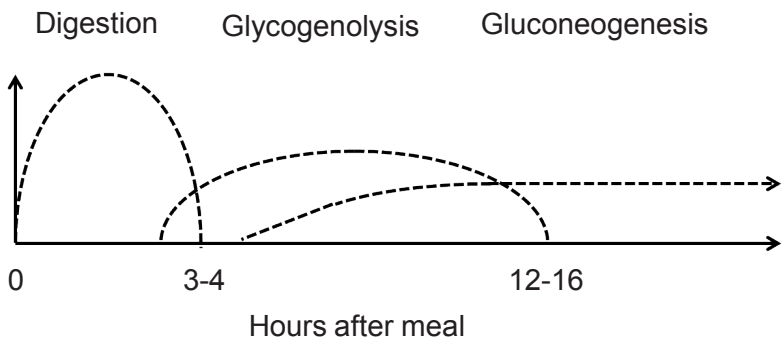

Fig. 1. Glucose source during fasting. hypoglycemia after an overnight fast. When the patient has hyperinsulinemia, hypoglycemic episodes can occur at any time point, sometimes even at 2 hours after the last meal.

(2) Does the patient respond to glucagon injection?

When hypoglycemia is caused by a defect in glycogenolysis, the patient does not respond to intramuscular/intravenous injection of glucagon, which stimulates glycogenolysis. Similarly, when a patient has a defect in gluconeogenesis, by the time the patient becomes hypoglycemic, the glycogen storage in the liver should have been exhausted; therefore the patient does not respond to glucagon either. Only when the patient has hyperinsulinemia can hepatic glycogen be mobilized by glucagon, and glycemic response $(>1.7-2.0 \mathrm{mmol} / \mathrm{L})$ is seen.

(3) What is the amount of glucose infusion needed to keep the patient euglycemic?

When hypoglycemia is caused by etiologies other than hyperinsulinism, euglycemia should be maintained by providing the amount of intravenous glucose that corresponds to the normal hepatic (or possibly renal) glucose output: $4-6 \mathrm{mg} / \mathrm{kg} / \mathrm{min}$ in neonates, $1-2 \mathrm{mg} / \mathrm{kg} / \mathrm{min}$ in adults, and intermediate values in older children. When euglycemia cannot be maintained by these amounts of continuous glucose infusion, clinicians may suspect the presence of hyperinsulinemia.

\section{2) Laboratory evidence of hyperinsulinism}

(1) Insulin at hypoglycemia

$\mathrm{HI}$ is diagnosed by demonstrating inappropriately elevated insulin in the presence of hypoglycemia $(<2.5 \mathrm{mmol} / \mathrm{L}, 45 \mathrm{mg} /$ $\mathrm{dL}$ ). However, it is often difficult to prove hyperinsulinemia by a critical sample taken during a hypoglycemic event ${ }^{11,12}$. In addition, the term "inappropriately elevated" insulin level is not precisely defined: some authors suggest that any detectable level of insulin is abnormal ${ }^{8,9}$, whereas others propose different cutoffs ${ }^{13)}$. With regard to the insulin levels during hypoglycemia, "any detectable level" is probably an overstatement because it may suggest but not prove HI. The cutoffs depend on the sensitivity of the particular assay as well as on the insulin sensitivity of each patient. In our own series of 94 confirmed Asian patients with $\mathrm{CHI}$, the insulin at hypoglycemia ranged

Table 1. Diagnosis of hyperinsulinemic hypoglycemia

\begin{tabular}{|c|c|c|c|c|c|}
\hline & $\begin{array}{l}\text { Serum insulin at } \\
\text { hypoglycemia, } \\
\text { pmol/L }(\mu \mathrm{U} / \mathrm{mL})\end{array}$ & $\begin{array}{c}\text { Glucose infusion rate to } \\
\text { maintain euglycemia } \\
\text { (mg/kg/min) }\end{array}$ & $\begin{array}{l}\text { Glycemic response to } \\
\text { glucagon, } \\
\text { mmol/L (mg/dL) }\end{array}$ & Free fatty acid/ketone bodies & Ref. \\
\hline 1 & ND & $>8$ & $>1.5(27)$ & ND & 10 \\
\hline 2 & Any detectable level & $\begin{array}{c}>10 \text { (neonate) } \\
>7 \text { (5 years old), }>4 \text { (adults) }\end{array}$ & $>1.7(30)$ & $\begin{array}{c}\text { Inappropriately low fatty } \\
\text { acids and ketones }\end{array}$ & 9 \\
\hline 3 & $>6.95(1)$ & ND & $>2-3(36-54)$ & $\begin{array}{c}\text { Negative ketone bodies in } \\
\text { urine/plasma }\end{array}$ & 13 \\
\hline 4 & Any detectable level & $>8$ & ND & ND & 8 \\
\hline Proposed criteria & $>20.84(3)$ & $\begin{array}{c}>8 \text { (neonates), >3 (adults), } \\
\text { in-betweens (children) }\end{array}$ & $>2(36)$ & $\begin{array}{l}\text { 3-hydroxybutylate }<1.3 \\
\mathrm{mmol} / \mathrm{L}, \mathrm{FFA}<1 \mathrm{mmol} / \mathrm{L}\end{array}$ & \\
\hline
\end{tabular}

ND, not described; FFA, free fatty acid. 
8.75-1,250 $\mathrm{pmol} / \mathrm{L}(1.26-180 \mu \mathrm{U} / \mathrm{mL})$ with a median of 73.3 $\mathrm{pmol} / \mathrm{L}(10.55 \mu \mathrm{U} / \mathrm{mL}$; unpublished data). In contrast, insulin levels during hypoglycemic events in patients without $\mathrm{HI}$ ranged from undetectable to $43.1 \mathrm{pmol} / \mathrm{L}(6.2 \mu \mathrm{U} / \mathrm{mL})$ while the detection limit was $>2.1 \mathrm{pmol} / \mathrm{L}(0.3 \mu \mathrm{U} / \mathrm{mL})$. Clearly, these values overlap.

(2) Relatively low free fatty acid and ketone bodies at hypoglycemia

Insulin inhibits lipolysis; therefore, low free fatty acid and ketone bodies during hypoglycemia are also used as diagnostic adjuncts. In normal infants (0-24 months of age), blood 3 -hydroxybutylate and free fatty acid levels after a 20-hour fast are $3.11 \mathrm{mmol} / \mathrm{L}$ (range, $1.29-4.34 \mathrm{mmol} / \mathrm{L}$ ) and $2.15 \mathrm{mmol} /$ $\mathrm{L}$ (range, $1.03-3.24 \mathrm{mmol} / \mathrm{L}$ ), respectively ${ }^{14}$. These values can be used to set cutoffs for HI. In our series of 207 cases with confirmed CHI, the highest 3-hydroxybutylate at hypoglycemia was $0.44 \mathrm{mmol} / \mathrm{L}$ (unpublished data).

\section{3) Proposed diagnostic criteria to suspect HI}

It is difficult to set definitive diagnostic criteria for HI. Several authors propose different cutoff values to diagnose HI (Table 1), but these criteria should be regarded as suggestive and not necessarily diagnostic. The bottom of Table 1 includes proposed criteria that strongly suggest the presence of $\mathrm{HI}$ in children.

\section{Treatment goals of $\mathrm{CHI}$}

The goals of HI treatment are to prevent neurological sequelae of hypoglycemia. Factors that could affect neurological outcomes include age, comorbid conditions, severity of the initial episode, and duration and frequency of subsequent hypoglycemic episodes ${ }^{15-18)}$. Therefore, the treatment goals should be individualized. Currently, blood glucose $>3.33-3.89$ $\mathrm{mmol} / \mathrm{L}(60-70 \mathrm{mg} / \mathrm{dL})$ is the most commonly recommended target for HI treatment ${ }^{10,11,13)}$.

\section{Insulin secretion and the ATP-sensitive potassium channel}

\section{Glucose induced insulin secretion (the GSIS pathway)} (Fig. 2)

In pancreatic $\beta$-cells, extracellular glucose is transported into the cytoplasm by the action of glucose transporter (GLUT2). The glucose is then phosphorylated by glucokinase. Glucokinase is not easily saturated by the physiological range of intracellular glucose, and is not inhibited by its end product glucose- 6 phosphate. Therefore, it serves as the fuel gauge of the $\beta$-cells. Glucose-6-phosphate is then metabolized via glycolysis, the Krebs cycle, and oxidative phosphorylation to generate ATP. An increased ATP/ADP ratio within $\beta$-cells leads to the closure of the ATP-sensitive potassium channel $\left(\mathrm{K}_{\mathrm{ATP}}\right.$ channel), which causes depolarization of the cell membrane and opening of the voltage-gated calcium channel. The resulting influx of calcium ions then causes fusion of the insulin secretory granules with the cell membrane and secretion of insulin ${ }^{19)}$.

\section{The $\mathrm{K}_{\text {ATP }}$ channel}

The $K_{\text {ATP }}$ channel is an octameric structure composed of four molecules of pore-forming Kir6.2 and four molecules of SUR1 that surround the pore and regulate the channel activity.

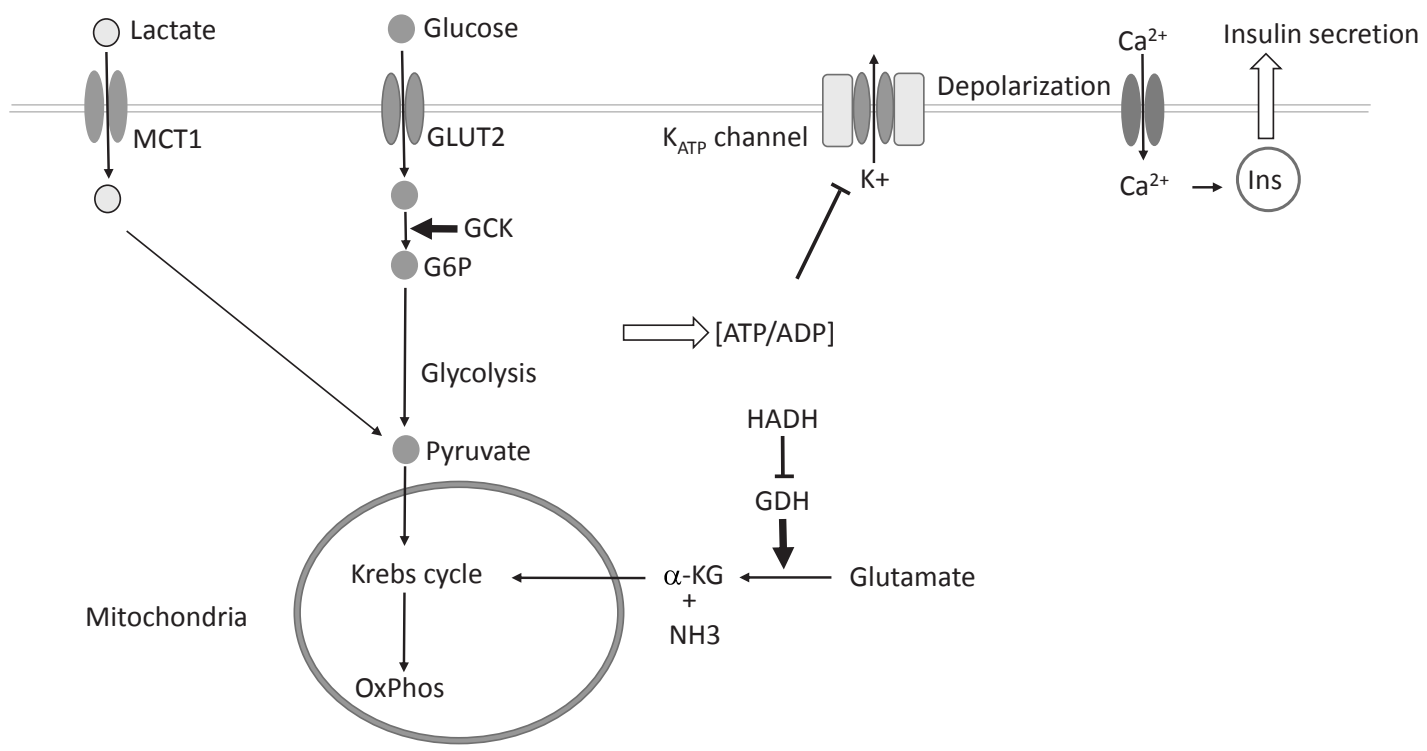

Fig. 2. The glucose-induced insulin secretion pathway. GLUT2, glucose transporter 2; GCK, glucokinase; G6P, glucose 6-phosphate; MCT1, monocarboxylate transporter 1; GDH, glutamate dehydrogenase; HADH, L-3-hydroxyacyl-coenzyme A dehydrogenase; $\alpha$-KG, $\alpha$-ketoglutarate; Ins, insulin. 
Intracellular ATP binds to Kir6.2 molecules to inhibit the channel activity, whereas MgADP binds to SUR1 to activate the channel. Therefore, channel activity is controlled by the ATP/ ADP ratio within the cells.

In the endoplasmic reticulum, Kir6.2 and SUR1 associate with each other to form the channel that is transferred to the Golgi apparatus and to the cell surface. If Kir6.2 and SUR1 do not associate with each other, they cannot escape the endoplasmic reticulum and are degraded there.

Kir6.2 and SUR1 are encoded by KCNJ11 (1 exon) and ABCC8 (39 exons), respectively. These genes are located side-byside with close proximity on $11 \mathrm{p} 15.1$.

\section{Known etiologies of CHI (Table 2)}

\section{Transient and persistent $\mathrm{CHI}$}

There are two main types of $\mathrm{CHI}$ : transient $\mathrm{CHI}$, which usually develops soon after birth and resolves spontaneously within the first 3-4 weeks of life and persistent $\mathrm{CHI}$, which can develop later in life as well as in the neonatel period, and lasts longer. The distinction between transient and persistent $\mathrm{CHI}$ is not possible on the basis of laboratory test results. In our national survey in Japan, only shorter gestational age and lighter birth weight were predictors of transient $\mathrm{CHI}^{20}$. The incidence of persistent $\mathrm{CHI}$ is generally estimated as 1 in 50,000 live births ${ }^{9)}$ although the incidence could be higher in certain populations (e.g., 1 in 2,500 births in Saudi Arabia). On the contrary, the incidence of transient $\mathrm{CHI}$ is much higher. In the national survey in Japan, the incidence of transient CHI (1 in 17,000 births) was approximately twice as high as that for persistent $\mathrm{CHI}(1 \text { in } 35,400 \text { births })^{20)}$.

\section{1) Transient CHI}

Transient $\mathrm{CHI}$ is believed to be caused mainly by nongenetic factors, e.g., small size for the infant's gestational age or stressful perinatal conditions such as cardiopulmonary disorders. An important exception is the monoallelic inactivating mutation in
$H N F 4 A^{21-23)}$. Unlike other patients with transient CHI, patients with HNF4A mutations are often born large for gestational age. Importantly, a fraction of these patients develop a form of dominantly inherited diabetes, maturity-onset diabetes of the young type 1 (MODY1), later in life and therefore should be followed up after resolution of CHI (21-23). Because HNF1A is in the same pathway with $H N F 4 A$ and its mutation is the cause of MODY3, researchers checked for mutations in HNF1A in patients with transient $\mathrm{CHI}$, and indeed found some patients with mutations in $H N F 1 A^{24,25)}$.

\section{2) Persistent $\mathrm{CHI}$}

In contrast, persistent $\mathrm{CHI}$ is believed to have genetic etiologies. However, even with the most comprehensive analysis, the responsible genes can be identified in only $53 \%$ of diazoxideresponsive $\mathrm{CHI}$ patients ${ }^{26)}$ although in unresponsive patients, $\mathrm{K}_{\text {ATP }}$ channel mutations could be identified in most $(87.6 \%-88 \%)$ cases $^{26,27)}$.

\section{Causes of persistent $\mathrm{CHI}$}

Table 2 lists known causes of CHI. The most common of these are inactivating mutations in one of the $\mathrm{K}_{\text {АтP }}$ channel genes, $A B C C 8$ or $K C N J 11$ ( $\left.\mathrm{K}_{\text {ATP }}-\mathrm{CHI}\right)$. The second most common is an activating mutation of glutamate dehydrogenase (GDH$\mathrm{CHI})$. Others are relatively rare. When confined to families with consanguinity, inactivating mutations in L-3-hydroxyacylcoenzyme A dehydrogenase (HADH-CHI) are the most common cause ${ }^{26,27)}$.

\section{1) $\mathrm{K}_{\mathrm{ATP}}$ - $\mathrm{CHI}$}

Three distinct subtypes of $\mathrm{K}_{\text {ATP }}$-CHI are known:

(1) Recessively-inherited $\mathrm{K}_{\mathrm{ATP}}$-CHI: Recessive $\mathrm{K}_{\mathrm{ATP}}$ - $\mathrm{CHI}$ is caused by biallelic mutations in one of the $\mathrm{K}_{\text {ATP }}$ channel genes. This is the most severe form of $\mathrm{K}_{\text {ATP }}$ - $\mathrm{CHI}$, and all $\beta$-cells in the pancreas present in abnormal (diffuse) form. Pathologically, recessive $\mathrm{K}_{\text {ATP- }} \mathrm{CHI}$ is characterized by large $\beta$-cells with abnormally enlarged nuclei ${ }^{28)}$.

Table 2. Genetic causes of congenital hyperinsulinism

\begin{tabular}{|c|c|c|c|c|}
\hline Gene & Protein & Chromosome & Inheritance & Note \\
\hline KATP channel & & & AR, AD, Focal & $\begin{array}{c}\text { Diazodixe unresponsive } \\
\text { Usher CHI } \\
\text { (contiguous deletion) }\end{array}$ \\
\hline$A B C C 8$ & SUR1 & $11 p 15.1$ & & \\
\hline KCNJ11 & Kir6.2 & $11 p 15.1$ & & \\
\hline GLUD1 & Glutamate dehydrogenase & $10 \mathrm{q} 23.3$ & $A D$ & Hyperammonemia \\
\hline GCK & Glucokinase & $7 p 15$ & $A D$ & Diffuse/focal? \\
\hline $\mathrm{HADH}$ & L-3-hydroxyacyl-coenzyme A dehydrogenase & $4 q 22-q 26$ & $A R$ & \\
\hline UCP2 & Uncoupling protein 2 & $11 q 13$ & $A D$ & \\
\hline SLC16A1 & Monocarboxylate transporter 1 & $1 p 12$ & $A D$ & Exercise induced $\mathrm{HI}$ \\
\hline HNF4A & Hepatocyte nuclear factor $4 a$ & $20 q 13.12$ & $A D$ & Transient/persistent macrosomia \\
\hline HNF1A & Hepatocyte nuclear factor $1 a$ & $12 q 24.2$ & $A D$ & Variable onset glycogenosis renal tubular dysfunction \\
\hline
\end{tabular}

$A R$, autosomal recessive; $A D$, autosomal dominant; $\mathrm{CHI}$, congenital hyperinsulinism; $\mathrm{HI}$, hyperinsulinism 
(2) Dominantly inherited $\mathrm{K}_{\mathrm{ATP}}$-CHI: Dominant $\mathrm{K}_{\mathrm{ATP}}$ - $\mathrm{CHI}$ is caused by a monoallelic mutation in the $\mathrm{K}_{\mathrm{ATP}}$ channel genes. The presentation is usually relatively milder, and patients often respond to diazoxide ${ }^{29)}$ although there are some refractory cases $^{30)}$.

(3) Focal $\mathrm{K}_{\text {ATP }}$-CHI:

i) Pathogenesis

In patients with focal $\mathrm{K}_{\mathrm{ATP}} \mathrm{CHI}$, abnormal $\beta$-cells are confined to a restricted region in the pancreas. In close proximity with the $K_{\text {ATP }}$ channel genes at chromosome 11p15.1, an imprinted region at 11 p 15.5 harbors maternally expressed tumor suppressors, $H 19$ and $C D K N 1 c$, and a paternally expressed growth factor gene, IGF2. The focal lesion arises in an individual with a paternally inherited, monoallelic mutation in one of the $\mathrm{K}_{\text {АTP }}$ channel genes. When segmental paternal uniparental disomy occurs as a somatic mutation during the development of the pancreas, that particular cell loses $\mathrm{K}_{\mathrm{ATP}}$ channel activity. At the same time, the tumor-suppressor activities of H19 and CDKN1C are lost, and the activity of IGF2 is doubled. This leads to a growth advantage for the abnormal $\beta$-cells and eventually leads to formation of a focal lesion ${ }^{31-34)}$. Histologically, the focal lesion is characterized by the presence of large $\beta$-cells with enlarged nuclei similar to those of the diffuse lesion, and $\beta$-cells outside the focus have normal histology $\mathrm{y}^{35-37)}$.

ii) Clinical implication

Although $96.2 \%$ of focal lesions are unresponsive to diazoxide ${ }^{3)}$, when the focal lesion is identified preoperatively, partial pancreatectomy can cure the patient without postoperative complications. Therefore, the identification and localization of focal lesions are extremely important. However, because they are generated during the normal organogenesis of the pancreas, they cannot usually be detected using conventional imaging modalities such as computed tomography (CT), magnetic resonance imaging, and angiography. The focal lesions can be preoperatively identified using molecular analysis and ${ }^{18} \mathrm{~F}$-fluoro-L-DOPA positron emission tomography $\left({ }^{18} \mathrm{~F}\right.$-DOPA PET $)$ scans, thereby enabling surgeons to plan the surgical procedure and to find the lesion intraoperatively.

\section{iii) ${ }^{18}$ F-DOPA PET scan}

${ }^{18} \mathrm{~F}$-DOPA is incorporated into $\beta$-cells by DOPA-decarboxylase, which is abundant in $\beta$-cells. Following the initial description of its role in identifying the focal lesion ${ }^{38)}$, its usefulness has been reported in a number of publications ${ }^{39,40)} \cdot{ }^{18} \mathrm{~F}$-DOPA PET detects focal lesions as small as $5 \mathrm{~mm}$ and is better preformed as PET-CT. However, there are some challenges in interpreting the results. First, artifact uptakes tend to be found in the head of the pancreas because the head has a larger mass than the rest of the pancreas and because ${ }^{18} \mathrm{~F}$-DOPA is excreted into the bile duct. Second, ${ }^{18}$ F-DOPA PET does not necessarily show the exact size of the lesion, especially when the lesion extends so-called tentacles out of the central lesion. These problems appeared more pronounced in our experience in Japan ${ }^{41)}$. iv) Epidemiology of focal $\mathrm{K}_{\mathrm{ATP}}-\mathrm{CHI}$

Previously, it was reported that approximately 40\%-60\% of surgically treated patients had focal $\mathrm{CHI}^{31,42,43)}$. However, recent molecular analysis has revealed a racial disparity in the frequency of paternally inherited monoallelic mutation in $\mathrm{K}_{\text {ATP }}{ }^{-}$ CHI patients. For example, the percentage of patients with a paternally inherited monoallelic $\mathrm{K}_{\mathrm{ATP}}$-channel mutation is $20.6 \%$ in Spain ${ }^{44)}, 33 \%$ in Norway $^{45)}, 84.2 \%$ in Japan ${ }^{46)}, 37.7 \%$ in Germany $^{47)}, 58 \%$ in China ${ }^{48)}$, and $25 \%$ in the $\mathrm{UK}^{27)}$. Obviously, these figures could be affected by ascertainment biases and by small sample sizes. In Japan, we have presently identified 46 patients with $\mathrm{K}_{\mathrm{ATP}}-\mathrm{CHI}$, and 37 (80.4\%) have paternal mutations. Therefore, combined with the report from China ${ }^{48)}$, it appears that Asians tend to have a higher frequency of paternally inherited mutation, suggesting the presence of focal CHI. The identification of focal CHI, therefore, is even more important for Asian patients.

v) Discordant molecular and ${ }^{18} \mathrm{~F}$-DOPA PET results

Not all patients with a paternally inherited $K_{\text {ATP }}$ channel mutation have focal uptake by ${ }^{18} \mathrm{~F}$-DOPA PET, and some of these actually show diffuse histology. For example, Banerjee et al. ${ }^{49)}$ reported that $31 \%$ of patients with a paternal monoallelic mutation showed diffuse uptake on 18F-DOPA PET. Similarly, Kapoor et al. ${ }^{27)}$ reported that $26 \%$ of patients with paternal mutation appeared to have a diffuse lesion on PET. These results may indicate that not all maternal mutations were identified by the molecular analysis. However, when monoallelic mutations were identified in patients with $\mathrm{K}_{\mathrm{ATP}}$ - $\mathrm{CHI}$, the majority were paternal mutations: $79.3 \%$ and $65 \%$ in two UK series ${ }^{27,49)}, 84.2 \%$ in Japan ${ }^{46)}$, and $83.3 \%$ in Norway ${ }^{45)}$. Selectively missing the maternal allele during the molecular analysis is statistically highly unlikely. Another possibility, therefore, is that these patients have unusually scattered focal CHI that resembles true diffuse CHI. Further analysis is necessary to address this problem.

\section{2) Non- $\mathrm{K}_{\text {ATP }}$ channel CHI}

Most other persistent $\mathrm{CHI}$ are caused by excessive anaplerosis (replenishment of metabolic intermediate) into the GSIS pathway. With the exception of GCK and SLC16A1 mutations, these non- $\mathrm{K}_{\mathrm{ATP}}$-channel $\mathrm{CHI}$ are usually responsive to diazoxide.

\section{(1) GDH}

GDH is encoded by GLUD1 at chromosome 10q23.3. GDH mediates conversion of glutamate to a-ketoglutarate and ammonia, which is one of the major anaplerotic pathways in the Krebs cycle. An activating mutation in the GLUD1 gene then supplies excess $a$-ketoglutarate into the Krebs cycle. The resulting overproduction of ATP causes $\mathrm{CHI}$ associated with hyperammonemia (hyperinsulinism-hyperammonemia syndrome $)^{50)}$. Both dominantly inherited and sporadic cases have been reported. Hypoglycemia is responsive to diazoxide, but hyperammonemia is resistant to conventional treatment. 
Because GDH is allosterically activated by leucine, GDH-CHI presents with the typical leucine-sensitive CHI.

\section{3) $\mathrm{HADH}$}

HADH-previously known as short-chain hydroxyacyl CoA dehydrogenase-is encoded by $H A D H$ at $4 \mathrm{q} 22-\mathrm{q} 26$. HADH functions in the mitochondrial matrix to catalyze the oxidation of straight-chain 3-hydroxyacyl-CoAs as part of the $\beta$-oxidation pathway. Unlike other proteins in the $\beta$-oxidation pathway, HADH is abundant in pancreatic $\beta$-cells and inhibits the activity of GDH. Biallelic HADH mutation then causes activation of GDH and hyperinsulinemia ${ }^{51-53)}$.

\section{4) Glucokinase}

Glucokinase is encoded by GCK at chromosome $7 \mathrm{p} 15$. Patients with GCK-HI have an activating mutation in GCK. This leads to overactivity in the GSIS pathway and oversecretion of insulin ${ }^{54-56)}$. On the contrary, inactivating monoallelic mutation is a cause of MODY2 or GCK-MODY ${ }^{57)}$. Recently, a somatic activating mutation in GCK has been proposed as a cause of a novel form of diazoxide-responsive focal $\mathrm{CHI}^{58)}$.

\section{5) Uncoupling protein 2}

Mitochondrial uncoupling protein 2 (UCP2) is encoded by UCP2 at chromosome 11q13. UCP2 protein leaks protons across the inner mitochondrial membrane, thereby uncoupling the oxidative phosphorylation from ATP generation. Patients with a monoallelic mutation in UCP2 have excessive ATP production leading to $\mathrm{HI}^{59)}$.

6) Monocarboxylate transporter 1

Monocarboxylate transporter 1 (MCT1) encoded by SLC16A1 at $1 \mathrm{p} 12$ is in the cell membrane and transports extracellular lactate and pyruvate into the cells. In pancreatic $\beta$-cells, the activity of MCT1 is normally suppressed to prevent lactate influx during exercise. In patients with exerciseinduced $\mathrm{HI}$, researchers identified mutations in the promoter of SLC16A1 that activate the transporter. During exercise, extracellular lactate is fluxed into the $\beta$-cells and is converted to pyruvate, which fuels the GSIS pathway. The resulting increase in ATP production leads to $\mathrm{HI}^{60)}$.

\section{Syndromic $\mathrm{CHI}$}

A variety of syndromes are reportedly associated with CHI Because $\mathrm{CHI}$ is not a common feature of these syndromes, some of these associations may be coincidental. Nevertheless, CHI is frequently associated with Beckwith-Wiedemann syndrome, Sotos syndrome, Kabuki syndrome, Costello syndrome, mosaic Turner syndrome, or congenital deficiency of glycosylation ${ }^{61)}$. In these syndromes, the association may have biological implications more than by-chance association. Of note is the Usher-CHI syndrome ${ }^{62,63)}$ in which $\mathrm{CHI}$ is associated with the symptoms of Usher syndrome, i.e., hearing loss and retinitis pigmentosa. This association is caused by biallelic deletions encompassing the $\mathrm{K}_{\text {ATP }}$ channel genes at $15 \mathrm{p} 11$ and the adjacent USH1C gene at 11 p14.3, which is responsible for Usher syndrome.

\section{Current treatment strategies}

Current treatment strategies are summarized in Table 3 and are reviewed below.

\section{Diazoxide}

Diazoxide is a benzothiazine derivative that acts on the SUR1 subunit of the $K_{\text {ATP }}$ channel, activating it. Diazoxide is used orally in three divided doses $(5-15 \mathrm{mg} / \mathrm{kg} /$ day $)$ and is effective for a variety of CHI subtypes ${ }^{64)}$. However, it is generally ineffective for the most severe, neonatal-onset, recessive, and focal forms of $\mathrm{K}_{\text {ATP }}$ - CHI. Dominant $\mathrm{K}_{\text {ATP }}$ channel CHI often responds to diazoxide, although some unresponsive cases have been reported $^{32)}$. Hypertrichosis occurs in most patients and could be a serious concern. Other side effects include water retention, which could cause serious problems such as congestive heart failure or reopening of the ductus arteriosus ${ }^{65,66)}$. This side effect may be of particular concern in patients with a low birth weight, as in transient CHI. Routine coadministration of diuretics is advised.

\section{Octreotide}

Octreotide is a somatostatin analog that acts on the somatostatin receptors SSTR2 and SSTR5 and inhibits secretion of a variety of hormones, including gastrin, cholecystokinin, glucagon, growth hormone, secretin, pancreatic polypeptide, thyroid stimulating hormone (TSH) vasoactive intestinal peptide, and insulin. Although its use for CHI has not been licensed in any country, it has been used for nearly 20 years for both short- and long-term control of diazoxide-unresponsive $\mathrm{CHI}^{67,68)}$. It is administered as multiple daily subcutaneous injections (3-4 times/day) or by continuous subcutaneous infusions using an insulin pump. In our experience, many

Table 3. Treatment for congenital hyperinsulinism

\begin{tabular}{l} 
Nutritional \\
Hypertonic glucose infusion \\
Cornstarch \\
Glycogen storage disorder formula \\
Enteral feeding (nasogastric tube feeding, gastrostomy) \\
Medical \\
Diazoxide, $5-20 \mathrm{mg} / \mathrm{kg} /$ day, po \\
Nifedipine, $0.25-2.5 \mathrm{mg} / \mathrm{kg} /$ day, po \\
Octreotide, $5-25 \mu \mathrm{g} / \mathrm{kg} /$ day, sc \\
Glucagon, $1-20 \mu \mathrm{g} / \mathrm{kg} / \mathrm{hr}$, sc, iv, im \\
Surgical \\
Pancreatectomy (partial, subtotal, neartotal) \\
\hline po, per oral; sc, subcutanetous; iv, intravenous; im, intramuscular.
\end{tabular}


patients with $\mathrm{K}_{\text {ATP }}$ channel CHI can be maintained on long-term treatment until spontaneous remission at 2-5 years of age ${ }^{69)}$. Common adverse events include gastrointestinal symptoms, white stool, dilated gall bladder with or without gall stones, and growth deceleration after 2 years of age. Rarer, but more serious side effects, include hepatitis ${ }^{70)}$, necrotizing enterocolitis ${ }^{71)}$ and long QT syndrome ${ }^{72)}$.

\section{Glucagon}

Glucagon stimulates glycogenolysis and gluconeogenesis to increase hepatic glucose output. It is administered by intravenous, subcutaneous, or intramuscular routes, and has been used mainly for short-term control of diazoxideunresponsive patients who are not adequately controlled by other means. However, as is the case for octreotide, its longterm use until spontaneous remission has been reported ${ }^{73,74)}$ Apart from its gastrointestinal side effects, its crystallization in the infusion tubes has been a major practical problem during long-term use. Part of this problem may be ameliorated by the development of a water-soluble formulation that is in a phase 2 clinical trial (ClinicalTrials.gov Identifier: NCT01972152).

\section{Pancreatectomy}

When patients are not responsive to medical treatment and cannot be weaned off treatment with intravenous glucose infusions, pancreatectomy should be considered. When a focal lesion is identified preoperatively, partial pancreatectomy is the treatment of choice. However, the lesion is not always visible or palpable at the site indicated by ${ }^{18} \mathrm{~F}$-DOPA PET. Although intraoperative sonography can aid in identification ${ }^{75)}$, repeated intraoperative biopsy may be necessary to help surgeons determine the extent of pancreatectomy. Such a treatment is made possible only by a multidisciplinary team composed of surgeons, radiologists, pediatric endocrinologists, and pathologists who are well experienced in the treatment of $\mathrm{CHI}^{76,77)}$. When a focal lesion is identified in the body or tail of the pancreas using ${ }^{18} \mathrm{~F}$-DOPA PET, resection is relatively easy; even if the exact location of the focal lesion cannot be identified, distal pancreatectomy of $<70 \%$ typically cures the patient without a risk of postoperative diabetes. On the contrary, when the lesion is identified in the head of the pancreas, resection may be difficult without damaging important adjacent structures such as the main pancreatic duct or the common bile duct. In those cases, pancreatic head resection with Rouxen-Y reconstruction of distal pancreatojejunostomy has been proposed $^{78)}$. For patients with diazoxide-unresponsive diffuse $\mathrm{CHI}$, extended resection of the pancreas is still needed. Even in these cases, near-total pancreatectomy should be avoided as much as possible in order to reduce the development of postsurgical diabetes ${ }^{79,80)}$. A $70 \%-90 \%$ resection may be considered to reduce the pancreatic mass and to facilitate medical management.

\section{Other unsolved questions and future perspectives}

\section{Causes of the remaining $50 \%$ of persistent $\mathrm{CHI}$}

At present, even with the most comprehensive molecular analysis, mutations in known causative genes cannot be identified in $21.3 \%$ of patients ${ }^{26)}$. When confined to diazoxideresponsive cases, mutations are not identified in 53\%. Therefore, if we assume that all persistent $\mathrm{CHI}$ is genetic in origin, there must be unidentified causative genes. In an effort to address this issue, Proverbio et al. ${ }^{81)}$ analyzed 17 families with $\mathrm{CHI}$ who lacked mutations in $A B C C 8 / K C N J 11$ using a combination of transmission disequilibrium tests and whole-exome sequencing and reported 21 novel genes as possible candidates. Although none of these have been confirmed as causative, further efforts employing next-generation sequencing may answer these questions.

Using next-generation sequencing, Flanagan et al. ${ }^{82)}$ took a different approach of sequencing the entire genomic region of the $A B C C 8$ and $H A D H$ genes $^{82)}$. By this strategy, they identified deep intronic mutations of both genes causing CHI, c.1333$1013 \mathrm{~A}>\mathrm{G}$ in $A B C C 8$ and c.636p471G $>\mathrm{T} H A D H$. Surprisingly, these mutations were common in the Irish and Turkish populations, accounting for $14 \%$ of focal hyperinsulinism cases and $32 \%$ of subjects with HADH mutations.

\section{Causes of transient $\mathrm{CHI}$ (a hypothesis)}

Transient CHI is common in infants who were born small for their gestational ages (SGA) or in those with perinatal stress. However, little is known about its cause. SGA infants are in a hypoxemic condition in utero ${ }^{83)}$. Because $\beta$-cell function is inhibited by hypoxia-inducible factor $1 \alpha(\mathrm{HIF} 1 \alpha)^{84,85)}$, a sudden increase in the oxygen tension at delivery may downregulate HIF 1 a leading to hyperinsulinemia. In line with the observation that oxygenation of fetal blood improves with gestational ages ${ }^{83)}$, it has been reported that blood insulin levels at birth correlate with the gestational age of the infants: $9.2 \mu \mathrm{IU} / \mathrm{mL}$ for full term; $10.3 \mu \mathrm{IU} / \mathrm{mL}$ for early term; $13.2 \mu \mathrm{IU} / \mathrm{mL}$ for late preterm; and $18.9 \mu \mathrm{IU} / \mathrm{mL}$ for early preterm ${ }^{86}$. Hyperinsulinemia at birth, therefore, is a common finding in newborns with a lower birth weight.

\section{Mechanism of spontaneous remission of $\mathrm{CHI}$}

Both diffuse and focal HI resolve spontaneously over time ${ }^{87)}$. A previously proposed mechanism for spontaneous remission of $\mathrm{CHI}$ is apoptotic death of insulin-oversecreting $\beta$-cells ${ }^{88)}$. However, the initial event could be functional shutdown of insulin secretion rather than apoptotic cell death because the abnormal $\beta$-cells could still be observed by ${ }^{18} \mathrm{~F}$-DOPA PET at an early stage of the spontaneous remission of focal $\mathrm{K}_{\mathrm{ATP}}-\mathrm{CHI}^{89)}$. Manipulating the process of functional shutoff could be an 
attractive treatment option for CHI.

\section{Novel medications for diazoxide-unresponsive $\mathrm{CHI}$}

1) Novel somatostatin analogues

Novel somtatostatin analogues have been successfully used for CHI or other forms of HI, including lanreotide ${ }^{90,91)}$ or longacting octreotide $^{92)}$ for CHI. In addition, pasireotide has been tested for severe postgastric bypass $\mathrm{HI}^{93)}$. Although octreotide and lanreotide have affinities for somatostatin receptors SSTR2 and SSTR5, pasireotide has a broader spectrum of activity for other types of SSTRs ${ }^{94)}$.

2) Small molecule corrector of $\mathrm{K}_{\mathrm{ATP}}$-channel $\mathrm{CHI}$

The search for small molecules to treat CHI is fueled by previous efforts to correct the trafficking defect of the cystic fibrosis transmembrane conductance regulator, which is deficient in patients with cystic fibrosis. The idea is to use small molecules as pharmacological chaperones to correct the trafficking defect and help their expression to the cell surface ${ }^{95)}$. This strategy is applicable to certain mutations of the $\mathrm{K}_{\mathrm{ATP}}$-channel genes. Thus far, sulfonylureas ${ }^{96)}$ and carbamazepine ${ }^{97)}$ have been successfully used to correct the trafficking defects of mutations within the transmembrane domains 0 and 1 (TMD0, TMD1) of ABCC8.

3) Glucagon-like peptide 1 (GLP1) receptor antagonist

GLP1 is secreted from the L-cells of the small intestine and binds to the GLP1 receptors in pancreatic $\beta$-cells, thereby stimulating the secretion of insulin (the incretin pathway). This pathway has a role in the amplification of postprandial insulin secretion and has been the target of novel treatments for type 2 diabetes. An antagonist of the GLP1 receptor, exendin ${ }^{9-39)}$, has been shown to be effective for the treatment of $\mathrm{CHI}$ in an open-label, randomized clinical trial ${ }^{98)}$. Although the effect was not complete, and monotherapy of $\mathrm{CHI}$ with this class of medication appears impractical, GLP1 receptor antagonists may have a role in adjunctive treatment of $\mathrm{CHI}$.

4) Mammalian target of rapamycin (mTOR) inhibitors

mTOR is a member of the serine/threonine kinase family and is induced by amino acids (arginine and branched-chain amino acids), stress, high-energy status, oxygen, and growth factors. mTOR is complexed with regulatory-associated protein of mTOR (Raptor), mammalian LST8/G-protein $\beta$-subunitlike protein (mLST8/G $\beta$ L), PRAS40, and DEPTOR to form the mTORC1 complex. Alternatively, mTOR is complexed with $\mathrm{mLST} / \mathrm{G} \beta$, rapamycin-insensitive companion of mTOR (Rictor), and mammalian stress-activated protein kinaseinteracting protein $1(\mathrm{mSIN} 1)$ to form $\mathrm{mTORC} 2$ and is active in a variety of cellular mechanisms, including protein synthesis, cell proliferation, or cell survival. Therefore, mTOR inhibitors have been widely used to treat neoplasms. In terms of glucose metabolism, activation of mTORC1 is known to cause increased glucose uptake and glycolysis via HIF1. In addition, mTORC2 is known to play an important role in maintaining the $\beta$-cell mass through the phosphotidylinositol-3-kinase/mTORC2/AKT signaling pathway ${ }^{99)}$. Sirolimus, one of the mTOR inhibitors, was successfully used to treat patients with diazoxide unresponsive $\mathrm{CHI}^{100)}$. These classes of medications therefore may have a role in the treatment of $\mathrm{CHI}$ as well.

\section{Conflict of interest}

No potential conflict of interest relevant to this article was reported.

\section{Acknowledgments}

This work was supported by a Grant-in-aid for Scientific Research from the Ministry of Health, Labour and Welfare of Japan (Research on Measures for Intractable Diseases 2012 070).

\section{References}

1. Menni F, de Lonlay P, Sevin C, Touati G, Peigne C, Barbier $\mathrm{V}$, et al. Neurologic outcomes of 90 neonates and infants with persistent hyperinsulinemic hypoglycemia. Pediatrics 2001;107:476-9.

2. Steinkrauss L, Lipman TH, Hendell CD, Gerdes M, Thornton PS, Stanley CA. Effects of hypoglycemia on developmental outcome in children with congenital hyperinsulinism. J Pediatr Nurs 2005;20:109-18.

3. Ludwig A, Ziegenhorn K, Empting S, Meissner T, Marquard J, Holl R, et al. Glucose metabolism and neurological outcome in congenital hyperinsulinism. Semin Pediatr Surg 2011;20:45-9.

4. Avatapalle HB, Banerjee I, Shah S, Pryce M, Nicholson J, Rigby L, et al. Abnormal neurodevelopmental outcomes are common in children with transient congenital hyperinsulinism. Front Endocrinol (Lausanne) 2013;4:60.

5. Shilyansky J, Fisher S, Cutz E, Perlman K, Filler RM. Is 95\% pancreatectomy the procedure of choice for treatment of persistent hyperinsulinemic hypoglycemia of the neonate? J Pediatr Surg 1997;32:342-6.

6. Meissner T, Wendel U, Burgard P, Schaetzle S, Mayatepek E. Long-term follow-up of 114 patients with congenital hyperinsulinism. Eur J Endocrinol 2003;149:43-51.

7. Levy-Shraga Y, Pinhas-Hamiel O, Kraus-Houminer E, Landau H, Mazor-Aronovitch K, Modan-Moses D, et al. Cognitive and developmental outcome of conservatively treated children with congenital hyperinsulinism. J Pediatr Endocrinol Metab 2013;26:301-8.

8. Hussain K. Diagnosis and management of hyperinsulinaemic hypoglycaemia of infancy. Horm Res 2008;69:2-13.

9. Arnoux JB, Verkarre V, Saint-Martin C, Montravers 
F, Brassier A, Valayannopoulos V, et al. Congenital hyperinsulinism: current trends in diagnosis and therapy. Orphanet J Rare Dis 2011;6:63.

10. Mohamed Z, Arya VB, Hussain K. Hyperinsulinaemic hypoglycaemia:genetic mechanisms, diagnosis and management. J Clin Res Pediatr Endocrinol 2012;4:169-81.

11. Palladino AA, Bennett MJ, Stanley CA. Hyperinsulinism in infancy and childhood: when an insulin level is not always enough. Clin Chem 2008;54:256-63.

12. De Leon DD, Stanley CA. Determination of insulin for the diagnosis of hyperinsulinemic hypoglycemia. Best Pract Res Clin Endocrinol Metab 2013;27:763-9.

13. Arnoux JB, de Lonlay P, Ribeiro MJ, Hussain K, Blankenstein O, Mohnike K, et al. Congenital hyperinsulinism. Early Hum Dev 2010;86:287-94.

14. van Veen MR, van Hasselt PM, de Sain-van der Velden MG, Verhoeven N, Hofstede FC, de Koning TJ, et al. Metabolic profiles in children during fasting. Pediatrics 2011;127:e1021-7.

15. Vannucci RC, Vannucci SJ. Hypoglycemic brain injury. Semin Neonatol 2001;6:147-55.

16. Salhab WA, Wyckoff MH, Laptook AR, Perlman JM. Initial hypoglycemia and neonatal brain injury in term infants with severe fetal acidemia. Pediatrics 2004;114:361-6.

17. Rozance PJ, Hay WW. Hypoglycemia in newborn infants: Features associated with adverse outcomes. Biol Neonate 2006;90:74-86.

18. Gataullina S, Dellatolas G, Perdry H, Robert JJ, Valayannopoulos V, Touati G, et al. Comorbidity and metabolic context are crucial factors determining neurological sequelae of hypoglycaemia. Dev Med Child Neurol 2012;54:1012-7.

19. Ashcroft FM, Rorsman P. K(ATP) channels and islet hormone secretion: new insights and controversies. Nat Rev Endocrinol 2013;9:660-9.

20. Yorifuji T, Masue M, Nishibori H. Congenital hyperinsulinism: global and Japanese perspectives. Pediatr Int Forthcoming 2014. http://dx.doi.org/10.1111/ped.12390.

21. Pearson ER, Boj SF, Steele AM, Barrett T, Stals K, Shield JP, et al. Macrosomia and hyperinsulinaemic hypoglycaemia in patients with heterozygous mutations in the HNF4A gene. PLoS Med 2007;4:e118.

22. Kapoor RR, Locke J, Colclough K, Wales J, Conn JJ, Hattersley AT, et al. Persistent hyperinsulinemic hypoglycemia and maturity-onset diabetes of the young due to heterozygous HNF4A mutations. Diabetes 2008;57:1659-63.

23. Flanagan SE, Kapoor RR, Mali G, Cody D, Murphy N, Schwahn B, et al. Diazoxide-responsive hyperinsulinemic hypoglycemia caused by HNF4A gene mutations. Eur J Endocrinol 2010;162:987-92.

24. Stanescu DE, Hughes N, Kaplan B, Stanley CA, De Leon DD. Novel presentations of congenital hyperinsulinism due to mutations in the MODY genes: HNF1A and HNF4A. J Clin Endocrinol Metab 2012;97:E2026-30.

25. Colclough K, Bellanne-Chantelot C, Saint-Martin C,
Flanagan SE, Ellard S. Mutations in the genes encoding the transcription factors hepatocyte nuclear factor 1 alpha and 4 alpha in maturity-onset diabetes of the young and hyperinsulinemic hypoglycemia. Hum Mutat 2013;34:66985.

26. Snider KE, Becker S, Boyajian L, Shyng SL, MacMullen $\mathrm{C}$, Hughes N, et al. Genotype and phenotype correlations in 417 children with congenital hyperinsulinism. J Clin Endocrinol Metab 2013;98:E355-63.

27. Kapoor RR, Flanagan SE, Arya VB, Shield JP, Ellard S, Hussain K. Clinical and molecular characterisation of 300 patients with congenital hyperinsulinism. Eur J Endocrinol 2013; 168:557-64.

28. Sempoux C, Guiot Y, Jaubert F, Rahier J. Focal and diffuse forms of congenital hyperinsulinism: the keys for differential diagnosis. Endocr Pathol 2004;15:241-6.

29. Pinney SE, MacMullen C, Becker S, Lin YW, Hanna C, Thornton P, et al. Clinical characteristics and biochemical mechanisms of congenital hyperinsulinism associated with dominant KATP channel mutations. J Clin Invest 2008; 118:2877-86.

30. Macmullen CM, Zhou Q, Snider KE, Tewson PH, Becker SA, Aziz AR, et al. Diazoxide-unresponsive congenital hyperinsulinism in children with dominant mutations of the $\beta$-cell sulfonylurea receptor SUR1. Diabetes 2011;60: 1797-804.

31. de Lonlay P, Fournet JC, Rahier J, Gross-Morand MS, PoggiTravert F, Foussier V, et al. Somatic deletion of the imprinted 11 p15 region in sporadic persistent hyperinsulinemic hypoglycemia of infancy is specific of focal adenomatous hyperplasia and endorses partial pancreatectomy. J Clin Invest 1997;100:802-7.

32. Verkarre V, Fournet JC, de Lonlay P, Gross-Morand MS, Devillers M, Rahier J, et al. Paternal mutation of the sulfonylurea receptor (SUR1) gene and maternal loss of 11 p15 imprinted genes lead to persistent hyperinsulinism in focal adenomatous hyperplasia. J Clin Invest 1998;102: 1286-91.

33. Fournet JC, Mayaud C, de Lonlay P, Gross-Morand MS, Verkarre V, Castanet M, et al. Unbalanced expression of 11 p15 imprinted genes in focal forms of congenital hyperinsulinism: association with a reduction to homozygosity of a mutation in ABCC8 or KCNJ11. Am J Pathol 2001;158:2177-84.

34. Damaj L, le Lorch M, Verkarre V, Werl C, Hubert L, NihoulFekete C, et al. Chromosome 11 p15 paternal isodisomy in focal forms of neonatal hyperinsulinism. J Clin Endocrinol Metab 2008;93:4941-7.

35. Suchi M, Thornton PS, Adzick NS, MacMullen C, Ganguly A, Stanley CA, et al. Congenital hyperinsulinism: intraoperative biopsy interpretation can direct the extent of pancreatectomy. Am J Surg Pathol 2004;28:1326-35.

36. Suchi M, MacMullen CM, Thornton PS, Adzick NS, Ganguly A, Ruchelli ED, et al. Molecular and immunohistochemical analyses of the focal form of congenital hyperinsulinism. 
Mod Pathol 2006;19:122-9.

37. Rahier J, Guiot Y, Sempoux C. Morphologic analysis of focal and diffuse forms of congenital hyperinsulinism. Semin Pediatr Surg 2011;20:3-12.

38. Otonkoski T, Nanto-Salonen K, Seppanen M, Veijola R, Huopio H, Hussain K, et al. Noninvasive diagnosis of focal hyperinsulinism of infancy with [18F]-DOPA positron emission tomography. Diabetes 2006;55:13-8.

39. Blomberg BA, Moghbel MC, Saboury B, Stanley CA, Alavi A. The value of radiologic interventions and (18) F-DOPA PET in diagnosing and localizing focal congenital hyperinsulinism: systematic review and meta-analysis. Mol Imaging Biol 2013;15:97-105.

40. Yang J, Hao R, Zhu X. Diagnostic role of 18F-dihydroxyphenylalanine positron emission tomography in patients with congenital hyperinsulinism: a meta-analysis. Nucl Med Commun 2013;34:347-53.

41. Masue M, Nishibori H, Fukuyama S, Yoshizawa A, Okamoto S, Doi R, et al. Diagnostic accuracy of $\left[{ }^{18} \mathrm{~F}\right]$ fluoro-L-dihydroxyphenylalanine positron emission tomography scan for persistent congenital hyperinsulinism in Japan. Clin Endocrinol (Oxf) 2011;75:342-6.

42. Glaser B, Ryan F, Donath M, Landau H, Stanley CA, Baker $\mathrm{L}$, et al. Hyperinsulinism caused by paternal-specific inheritance of a recessive mutation in the sulfonylureareceptor gene. Diabetes 1999;48:1652-7.

43. De Leon DD, Stanley CA. Mechanisms of disease: advances in diagnosis and treatment of hyperinsulinism in neonates. Nat Clin Pract Endocrinol Metab 2007;3:57-68.

44. Fernandez-Marmiesse A, Salas A, Vega A, FernandezLorenzo JR, Barreiro J, Carracedo A. Mutation spectra of ABCC8 gene in Spanish patients with Hyperinsulinism of Infancy (HI). Hum Mutat 2006;27:214.

45. Sandal T, Laborie LB, Brusgaard K, Eide SA, Christesen $\mathrm{HB}$, Sovik O, et al. The spectrum of ABCC8 mutations in Norwegian patients with congenital hyperinsulinism of infancy. Clin Genet 2009;75:440-8.

46. Yorifuji T, Kawakita R, Nagai S, Sugimine A, Doi H, Nomura A, et al. Molecular and clinical analysis of Japanese patients with persistent congenital hyperinsulinism: predominance of paternally inherited monoallelic mutations in the KATP channel genes. J Clin Endocrinol Metab 2011;96:E141-5.

47. Mohnike K, Wieland I, Barthlen W, Vogelgesang S, Empting S, Mohnike W, et al. Clinical and genetic evaluation of patients with KATP channel mutations from the German registry for congenital hyperinsulinism. Horm Res Paediatr 2014;81:156-68.

48. Su C, Gong C, Sanger P, Li W, Wu D, Gu Y, et al. Longterm follow-up and mutation analysis of 27 chinese cases of congenital hyperinsulinism. Horm Res Paediatr 2014;81:169-76.

49. Banerjee I, Skae M, Flanagan SE, Rigby L, Patel L, Didi M, et al. The contribution of rapid KATP channel gene mutation analysis to the clinical management of children with congenital hyperinsulinism. Eur J Endocrinol 2011;164:7
33-40.

50. Stanley CA, Lieu YK, Hsu BY, Burlina AB, Greenberg CR, Hopwood NJ, et al. Hyperinsulinism and hyperammonemia in infants with regulatory mutations of the glutamate dehydrogenase gene. N Engl J Med 1998;338:1352-7.

51. Molven A, Matre GE, Duran M, Wanders RJ, Rishaug U, Njolstad PR, et al. Familial hyperinsulinemic hypoglycemia caused by a defect in the SCHAD enzyme of mitochondrial fatty acid oxidation. Diabetes 2004;53:221-7.

52. Flanagan SE, Patch AM, Locke JM, Akcay T, Simsek E, Alaei M, et al. Genome-wide homozygosity analysis reveals $\mathrm{HADH}$ mutations as a common cause of diazoxide-responsive hyperinsulinemic-hypoglycemia in consanguineous pedigrees. J Clin Endocrinol Metab 2011;96:E498-502.

53. Heslegrave AJ, Hussain K. Novel insights into fatty acid oxidation, amino acid metabolism, and insulin secretion from studying patients with loss of function mutations in 3-hydroxyacyl-CoA dehydrogenase. J Clin Endocrinol Metab 2013;98:496-501.

54. Kassem S, Bhandari S, Rodríguez-Bada P, Motaghedi R, Heyman M, Garcia-Gimeno MA, et al. Large islets, beta-cell proliferation, and a glucokinase mutation. N Engl J Med 2010;362:1348-50.

55. Barbetti F, Cobo-Vuilleumier N, Dionisi-Vici C, Toni S, Ciampalini P, Massa O, et al. Opposite clinical phenotypes of glucokinase disease: description of a novel activating mutation and contiguous inactivating mutations in human glucokinase (GCK) gene. Mol Endocrinol 2009;23:1983-9.

56. Christesen HB, Tribble ND, Molven A, Siddiqui J, Sandal T, Brusgaard K, et al. Activating glucokinase (GCK) mutations as a cause of medically responsive congenital hyperinsulinism: prevalence in children and characterisation of a novel GCK mutation. Eur J Endocrinol 2008;159:27-34.

57. Osbak KK, Colclough K, Saint-Martin C, Beer NL, Bellanne-Chantelot C, Ellard S, et al. Update on mutations in glucokinase (GCK), which cause maturity-onset diabetes of the young, permanent neonatal diabetes, and hyperinsulinemic hypoglycemia. Hum Mutat 2009;30:1512-26.

58. Henquin JC, Sempoux C, Marchandise J, Godecharles S, Guiot Y, Nenquin M, et al. Congenital hyperinsulinism caused by hexokinase I expression or glucokinase-activating mutation in a subset of $\beta$-cells. Diabetes 2013;62:168996.

59. Gonzalez-Barroso MM, Giurgea I, Bouillaud F, Anedda A, Bellanne-Chantelot C, Hubert L, et al. Mutations in UCP2 in congenital hyperinsulinism reveal a role for regulation of insulin secretion. PLoS One 2008;3:e3850.

60. Otonkoski T, Kaminen N, Ustinov J, Lapatto R, Meissner T, Mayatepek E, et al. Physical exercise-induced hyperinsulinemic hypoglycemia is an autosomal-dominant trait characterized by abnormal pyruvate-induced insulin release. Diabetes 2003;52:199-204.

61. Kapoor RR, James C, Hussain K. Hyperinsulinism in 
developmental syndromes. Endocr Dev 2009;14:95-113.

62. Bitner-Glindzicz M, Lindley KJ, Rutland P, Blaydon D, Smith VV, Milla PJ, et al. A recessive contiguous gene deletion causing infantile hyperinsulinism, enteropathy and deafness identifies the Usher type 1C gene. Nat Genet 2000;26:56-60.

63. Al Mutair AN, Brusgaard K, Bin-Abbas B, Hussain K, Felimban N, Al Shaikh A, et al. Heterogeneity in phenotype of usher-congenital hyperinsulinism syndrome: hearing loss, retinitis pigmentosa, and hyperinsulinemic hypoglycemia ranging from severe to mild with conversion to diabetes. Diabetes Care 2013;36:557-61.

64. Touati G, Poggi-Travert F, Ogier de Baulny H, Rahier J, Brunelle F, Nihoul-Fekete C, et al. Long-term treatment of persistent hyperinsulinaemic hypoglycaemia of infancy with diazoxide: a retrospective review of 77 cases and analysis of efficacy-predicting criteria. Eur J Pediatr 1998;157:628-33.

65. Demirel F, Unal S, Cetin II, Esen I, Arasli A. Pulmonary hypertension and reopening of the ductus arteriosus in an infant treated with diazoxide. J Pediatr Endocrinol Metab 2011;24:603-5.

66. Yoshida K, Kawai M, Marumo C, Kanazawa H, Matsukura T, Kusuda S, et al. High prevalence of severe circulatory complications with diazoxide in premature infants. Neonatology 2014;105:166-71.

67. Glaser B, Hirsch HJ, Landau H. Persistent hyperinsulinemic hypoglycemia of infancy: long-term octreotide treatment without pancreatectomy. J Pediatr 1993;123:644-50.

68. Thornton PS, Alter CA, Katz LE, Baker L, Stanley CA. Short- and long-term use of octreotide in the treatment of congenital hyperinsulinism. J Pediatr 1993;123:637-43.

69. Yorifuji T, Kawakita R, Hosokawa Y, Fujimaru R, Matsubara K, Aizu K, et al. Efficacy and safety of long-term, continuous subcutaneous octreotide infusion for patients with different subtypes of KATP-channel hyperinsulinism. Clin Endocrinol (Oxf) 2013;78:891-7.

70. Koren I, Riskin A, Barthlen W, Gillis D. Hepatitis in an infant treated with octreotide for congenital hyperinsulinism. J Pediatr Endocrinol Metab 2013;26:183-5.

71. Laje P, Halaby L, Adzick NS, Stanley CA. Necrotizing enterocolitis in neonates receiving octreotide for the management of congenital hyperinsulinism. Pediatr Diabetes 2010;11:142-7.

72. Celik N, Cinaz P, Emeksiz HC, Hussain K, Camurdan O, Bideci A, et al. Octreotide-induced long QT syndrome in a child with congenital hyperinsulinemia and a novel missense mutation (p.Met115Val) in the ABCC8 gene. Horm Res Paediatr 2013;80:299-303.

73. Mohnike K, Blankenstein O, Pfuetzner A, Potzsch S, Schober E, Steiner S, et al. Long-term non-surgical therapy of severe persistent congenital hyperinsulinism with glucagon. Horm Res 2008;70:59-64.

74. Neylon OM, Moran MM, Pellicano A, Nightingale M, O'Connell MA. Successful subcutaneous glucagon use for persistent hypoglycaemia in congenital hyperinsulinism. J Pediatr Endocrinol Metab 2013;26:1157-61.

75. von Rohden L, Mohnike K, Mau H, Eberhard T, Mohnike $\mathrm{W}$, Blankenstein $\mathrm{O}$, et al. Visualization of the focus in congenital hyperinsulinism by intraoperative sonography. Semin Pediatr Surg 2011;20:28-31.

76. Adzick NS, Thornton PS, Stanley CA, Kaye RD, Ruchelli E. A multidisciplinary approach to the focal form of congenital hyperinsulinism leads to successful treatment by partial pancreatectomy. J Pediatr Surg 2004;39:270-5.

77. Palladino AA, Stanley CA. A specialized team approach to diagnosis and medical versus surgical treatment of infants with congenital hyperinsulinism. Semin Pediatr Surg 2011;20:32-7.

78. Laje P, Stanley CA, Palladino AA, Becker SA, Adzick NS. Pancreatic head resection and Roux-en-Y pancreaticojejunostomy for the treatment of the focal form of congenital hyperinsulinism. J Pediatr Surg 2012;47:130-5.

79. Barthlen W, de Lonlay P. Congenital hyperinsulinism. Semin Pediatr Surg 2011;20:1-2.

80. Barthlen W. Surgery in congenital hyperinsulinism-tips and tricks not only for surgeons: a practical guide. Semin Pediatr Surg 2011;20:56-9.

81. Proverbio MC, Mangano E, Gessi A, Bordoni R, Spinelli R, Asselta R, et al. Whole genome SNP genotyping and exome sequencing reveal novel genetic variants and putative causative genes in congenital hyperinsulinism. PLoS One 2013;8:e68740.

82. Flanagan SE, Xie W, Caswell R, Damhuis A, Vianey-Saban C, Akcay T, et al. Next-generation sequencing reveals deep intronic cryptic ABCC8 and HADH splicing founder mutations causing hyperinsulinism by pseudoexon activation. Am J Hum Genet 2013;92:131-6.

83. Thompson LP, Al-Hasan Y. Impact of oxidative stress in fetal programming.J Pregnancy 2012;2012:582748.

84. Heinis M, Simon MT, Ilc K, Mazure NM, Pouyssegur J, Scharfmann R, et al. Oxygen tension regulates pancreatic beta-cell differentiation through hypoxia-inducible factor 1alpha. Diabetes 2010;59:662-9.

85. Hakim F, Kaitsuka T, Raeed JM, Wei FY, Shiraki N, Akagi T, et al. High oxygen condition facilitates the differentiation of mouse and human pluripotent stem cells into pancreatic progenitors and insulin-producing cells. J Biol Chem 2014;289:9623-38.

86. Wang G, Divall S, Radovick S, Paige D, Ning Y, Chen Z, et al. Preterm birth and random plasma insulin levels at birth and in early childhood. JAMA 2014;311:587-96.

87. Mazor-Aronovitch K, Landau H, Gillis D. Surgical versus non-surgical treatment of congenital hyperinsulinism. Pediatr Endocrinol Rev 2009;6:424-30.

88. Kassem SA, Ariel I, Thornton PS, Scheimberg I, Glaser B. Beta-cell proliferation and apoptosis in the developing normal human pancreas and in hyperinsulinism of infancy. Diabetes 2000;49:1325-33.

89. Yorifuji T, Hosokawa Y, Fujimaru R, Kawakita R, Doi 
H, Matsumoto T, et al. Lasting 18F-DOPA PET uptake after clinical remission of the focal form of congenital hyperinsulinism. Horm Res Paediatr 2011;76:286-90.

90. Modan-Moses D, Koren I, Mazor-Aronovitch K, Pinhas-Hamiel O, Landau H. Treatment of congenital hyperinsulinism with lanreotide acetate (Somatuline Autogel). J Clin Endocrinol Metab 2011;96:2312-7.

91. Kuhnen P, Marquard J, Ernert A, Meissner T, Raile K, Wannenmacher G, et al. Long-term lanreotide treatment in six patients with congenital hyperinsulinism. Horm Res Paediatr 2012;78:106-12.

92. Le Quan Sang KH, Arnoux JB, Mamoune A, Saint-Martin C, Bellanne-Chantelot C, Valayannopoulos V, et al. Successful treatment of congenital hyperinsulinism with long-acting release octreotide. Eur J Endocrinol 2012;166:333-9.

93. de Heide LJ, Laskewitz AJ, Apers JA. Treatment of severe postRYGB hyperinsulinemic hypoglycemia with pasireotide: a comparison with octreotide on insulin, glucagon, and GLP-1. Surg Obes Relat Dis 2013 Dec 4 [Epub].http://dx.doi.org/10.1016/j.soard.2013.11.006.

94. Feelders RA, de Herder WW, Neggers SJ, van der Lely AJ, Hofland LJ. Pasireotide, a multi-somatostatin receptor ligand with potential efficacy for treatment of pituitary and neuroendocrine tumors. Drugs Today (Barc) 2013;49:89103.
95. Martin GM, Chen PC, Devaraneni P, Shyng SL. Pharmacological rescue of trafficking-impaired ATP-sensitive potassium channels. Front Physiol 2013;4:386.

96. Yan FF, Casey J, Shyng SL. Sulfonylureas correct trafficking defects of disease-causing ATP-sensitive potassium channels by binding to the channel complex. J Biol Chem 2006;281:33403-13.

97. Chen PC, Olson EM, Zhou Q, Kryukova Y, Sampson HM, Thomas DY, et al. Carbamazepine as a novel small molecule corrector of trafficking-impaired ATP-sensitive potassium channels identified in congenital hyperinsulinism. J Biol Chem 2013;288:20942-54.

98. Calabria AC, Li C, Gallagher PR, Stanley CA, De Leon DD. GLP-1 receptor antagonist exendin-(9-39) elevates fasting blood glucose levels in congenital hyperinsulinism owing to inactivating mutations in the ATP-sensitive $\mathrm{K}+$ channel. Diabetes 2012;61:2585-91.

99. Gu Y, Lindner J, Kumar A, Yuan W, Magnuson MA. Rictor/ mTORC2 is essential for maintaining a balance between beta-cell proliferation and cell size. Diabetes 2011;60:82737.

100. Senniappan S, Alexandrescu S, Tatevian N, Shah P, Arya $V$, Flanagan S, et al. Sirolimus therapy in infants with severe hyperinsulinemic hypoglycemia. N Engl J Med 2014;370:1131-7. 